\title{
A systematic optimization of piggery wastewater treatment with
}

2 purple phototrophic bacteria.

3 Cristian A. Sepúlveda-Muñoz ${ }^{\text {a, b}}$, Ignacio de Godos ${ }^{\text {b, c }}$, Daniel Puyol ${ }^{\text {d }}$, Raúl Muñoz ${ }^{\text {a, }}$ $4 \quad \mathrm{~b}, *$

5

$6{ }^{a}$ Department of Chemical Engineering and Environmental Technology, School of 7 Industrial Engineering, University of Valladolid, Dr. Mergelina, s/n, 47011 Valladolid, 8 Spain.

$9 \quad{ }^{b}$ Institute of Sustainable Processes, Dr. Mergelina, s/n, 47011 Valladolid, Spain.

10 c School of Forestry, Agronomic and Bioenergy Industry Engineering (EIFAB),

11 University of Valladolid, Campus Duques de Soria, 42004, Soria, Spain.

$12{ }^{\mathrm{d}}$ Department of Chemical and Environmental Technology, ESCET, King Juan Carlos 13 University, 28933, Móstoles, Madrid, Spain.

14

$15 *$ Corresponding author: e-mail mutora@iq.uva.es (R. Muñoz) 


\section{Abstract}

22 The increase in natural water bodies pollution caused by intensive animal farming requires the development of innovative sustainable treatment processes. This study assessed the influence of piggery wastewater (PWW) load, air dosing, $\mathrm{CO}_{2} / \mathrm{NaHCO}_{3}{ }^{-}$ supplementation and $\mathrm{pH}$ control on PWW treatment by mixed cultures of purple phototrophic bacteria (PPB) under infrared radiation in batch photobioreactors. PPB was not able to grow in raw PWW but PWW dilution prevented inhibition and supported an effective light penetration. Despite the fact that PPB were tolerant to $\mathrm{O}_{2}$, carbon recovery decreased in the presence of air (induced by stripping). $\mathrm{CO}_{2}$ supplementation was identified as an effective strategy to maximize the removal of carbon during PPB-based PWW treatment with removal efficiencies of $72 \%$ and $74 \%$ for TOC and VFAs. However, the benefits derived from $\mathrm{CO}_{2}$ addition were induced by the indirect $\mathrm{pH}$ control exerted in the cultivation medium. Thus, PPB supported an optimal pollutant removal performance at $\mathrm{pH} 7$, with removal efficiencies of $75 \%, 39 \%$ and $98 \%$ for TOC, TN and VFAs.

Keywords: Nutrient recovery; PPB; Purple non-sulphur bacteria; Photosynthetic bacteria; Swine manure. 


\section{Introduction}

47 The uncontrolled discharge of wastewaters is a severe environmental problem worldwide. The contamination of natural water bodies with organic matter, nutrients, pathogens and toxic pollutants causes eutrophication of surface waters and limits the potential uses of water (García et al., 2019; Godos et al., 2010). Wastewaters are typically classified according to their origin into domestic, agricultural, industrial and agro-industrial wastewaters. Piggery wastewater (PWW) is an agro-industrial wastewater characterized by its high content of organic matter and nutrients (Chen et al., 2018) as a result of the limited use of process water during intensive pig farming. The need for a decentralized and cost-effective treatment of these high strength effluents is fostering research on the development of innovative and sustainable solutions to cope with this increasing environmental problem in rural areas (Godos et al., 2009).

In the past years, biotechnologies based on bacteria or microalgae growth have been engineered to treat wastewater since they entail a lower energy consumption and higher potential to recover nutrients compared to physical/chemical wastewater treatment technologies (García et al., 2019; Godos et al., 2009; Hülsen et al., 2018b, 2014). However, while anaerobic digestion is only capable of recovering the carbon and energy in the form of biogas (i.e. $\mathrm{CH}_{4}$ and $\mathrm{CO}_{2}$ ), the high concentrations of $\mathrm{NH}_{4}^{+}$typically encountered in PWW severely inhibit the growth of both microalgae and anaerobic microbial communities (Yenigün and Demirel, 2013). Therefore, there is a need to

67 develop new biotechnological platforms capable of maximizing carbon and nutrient recovery from PWW at reduced operating costs. 
In this context, purple phototrophic bacteria (PPB) constitute an emerging biological platform for the treatment of high strength wastewaters (Puyol et al., 2017). PPB exhibit high growth rates, can grow at high salinity (Hülsen et al., 2019), exhibit a versatile metabolism and are tolerant to low temperatures. Indeed, PPB are capable of carrying out an efficient domestic wastewater treatment process at temperatures of 10 and $11{ }^{\circ} \mathrm{C}$ (Dalaei et al., 2019; Hülsen et al., 2016a). In this context, psychrophilic PPBs capable of growing at temperatures ranging from 0 to $25^{\circ} \mathrm{C}$ have been isolated in the Antarctic (Madigan et al., 2000). Indeed, PPB can grow photoautotrophically and photoheterotrophically using light as energy source, and many forms of organic and inorganic compounds as electron donors. Likewise, PPB can grow chemoheterotrophically and chemoautotrophically using the energy from organic or inorganic compounds, respectively, and oxygen, nitrate/nitrite, or sugars as electron acceptors. PPB are capable of fixing carbon dioxide using phototrophic or chemoautotrophic metabolism, or using organic compounds as a carbon source under photoheterotrophic or chemoheterotrophic mode (Larimer et al., 2004). The phototrophic mechanism is remarkable as PPB use the near infrared range to power bacterial growth, which favors the selective cultivation of PPB (Hülsen et al., 2014). PPBs exhibit advantages compared to other photosynthetic microorganisms in terms of light utilization efficiency and tolerance to organic and nitrogen pollution. Thus, PPB have a higher conversion efficiency of photons $(6-8 \%)$ than microalgae $(<5 \%)$ (Posten and Schaub, 2009). A lower radiation intensity is required for effective PPB cultivation $\left(<50 \mathrm{~W} \mathrm{~m}^{-2}\right.$ ) compared to microalgae $\left(>200 \mathrm{~W} \mathrm{~m}^{-2}\right.$ ) (Gordon and Polle, 2007; Suwan et al., 2014). Infrared radiation is attenuated to a lesser extent than visible light in the culture broth, which entails a greater penetration of IR in high strength wastewaters (Hülsen et al., 2018b). Finally, PPB exhibit a high tolerance to organic and nitrogen 
pollution as a result of their versatile heterotrophic and mixotrophic metabolism (Lu et al., 2019b). Overall, PPB have been the dominant photosynthetic organisms in the mixed liquor of batch (Hülsen et al., 2018a) and continuous photobioreactors treating wastewaters under anaerobic conditions (Hülsen et al., 2018b). Most studies in literature have focused on the evaluation of the potential of PPB for carbon and nutrient removal in domestic wastewaters (Hülsen et al., 2016b, 2014), while the number of investigations assessing the optimization of the potential of PPB for the bioremediation of high-strength wastewaters such as PWW is very limited.

In this work, the potential of mixed cultures of PPB for the bioremediation of PWW was investigated in batch photobioreactors under infrared radiation. More specifically, the influence of the PWW load, air dosing, $\mathrm{CO}_{2} / \mathrm{NaHCO}_{3}{ }^{-}$supplementation and $\mathrm{pH}$ control on PPB growth and on carbon and nutrient removal from PWW was investigated.

\section{Materials and Methods}

\subsection{Piggery wastewater and inoculum}

The PWW, previously centrifuged in an industrial decanter, was collected from a swine farm at Narros de Cuéllar (Spain) and stored at $4{ }^{\circ} \mathrm{C}$. The PWW was further centrifuged for $10 \mathrm{~min}$ at $10000 \mathrm{rpm}$. The composition of the resulting PWW was as follows: total organic carbon (TOC) concentration of $15775 \pm 487 \mathrm{mg} \mathrm{\textrm {L } ^ { - 1 }}$, total carbon (TC) concentration of $16922 \pm 549 \mathrm{mg} \mathrm{L}^{-1}$, inorganic carbon (IC) concentration of $1149 \pm$ $223 \mathrm{mg} \mathrm{L}^{-1}$, total nitrogen (TN) concentration of $5028 \pm 339 \mathrm{mg} \mathrm{L}^{-1}$, total suspended solids (TSS) concentration of $4.3 \pm 0.3 \mathrm{~g} \mathrm{~L}^{-1}$ and $\mathrm{pH} 7.95 \pm 0.1$. 
119 The mixed PPB community inoculum used was obtained from a batch enrichment in 10

120 fold diluted PWW with Rhodopseudomonas as the dominant genus with a $82 \%$ relative

121 abundance (García et al., 2019). Fresh inoculum was prepared in 1.2 L gas-tight bottles

122 containing $400 \mathrm{~mL}$ of 10 fold diluted PWW under a He atmosphere. The inoculum was

123 incubated under magnetic agitation at $300 \mathrm{rpm}$ and infrared radiation at $50 \mathrm{~W} \mathrm{~m}^{-2}$.

\subsection{Chemical and reagents}

126

$\mathrm{CO}_{2}(\geq 99.9 \%)$ and Helium ( $\left.\geq 99.5 \%\right)$ were purchased from Abello Linde (Barcelona, Spain). $\mathrm{HCl}(\sim 37 \%)$ and $\mathrm{NaHCO}_{3}$ were obtained from Fisher Scientific (UK) and Cofarcas (Spain), respectively.

\subsection{Batch PWW biodegradation tests}

PWW biodegradation tests were performed batchwise in $1.2 \mathrm{~L}$ gas-tight glass bottles (Afora, Spain) in duplicate. The bottles were initially filled with $450 \mathrm{~mL}$ of the corresponding PWW and inoculated with $50 \mathrm{~mL}$ of fresh PPB inoculum. Unless otherwise specified, the bottles were then closed with butyl septa and plastic caps, and flushed with $\mathrm{He}$ for three minutes at a high flow rate in order to replace the air headspace with an inert atmosphere. An inert gas such as He without biological function was used to avoid any potential interference, since $\mathrm{N}_{2}$ can be fixed by PPB under specific cultivation conditions. The batch tests were incubated under magnetic agitation at $300 \mathrm{rpm}, 30 \pm 2{ }^{\circ} \mathrm{C}$ and infrared radiation of $50 \mathrm{~W} \mathrm{~m}^{-2}$ with light-emitting diodes OSLUX $^{\circledR}$ SFH 4780 S and SFH 4715AS, centroid emitting at a wavelength 810 and 850 nm, respectively (OSRAM, Germany). A non-inoculated control test using 10 fold diluted PWW and prepared as above described was also always conducted in each test series. A sample of $5 \mathrm{~mL}$ of liquid culture was taken every two days to analyze culture 
absorbance (samples were diluted with water in order to adjust the readings between 0.2 and 1.0), $\mathrm{pH}$ and the concentration of TOC, IC, TN and volatile fatty acids (VFA), while $100 \mu \mathrm{L}$ of the bottle headspace was drawn with gastight syringes (Hamilton, USA) to quantify the gas concentration of $\mathrm{CO}_{2}, \mathrm{H}_{2} \mathrm{~S}, \mathrm{CH}_{4}$. PPB growth was monitored using culture absorbance at $808 \mathrm{~nm}\left(\mathrm{OD}_{808}\right)$, which represents a specific spectral niche for these phototrophic microorganisms compared to other phototrophic species (Stomp et al., 2007). Thus, although the organic matter present in PWW preferentially absorbs at wavelengths under $700 \mathrm{~nm}$ (Fig. S1), PPB mainly absorb with characteristic peaks above $800 \mathrm{~nm}$ (Hülsen et al., 2019), corresponding to bacteriochlorophyll $a$ (Hunter et al., 2009).

\subsubsection{Test series 1}

The influence of PWW load on PPB growth and carbon and nitrogen removal from PWW was assessed in Test series 1 (Fig. S2) in order to elucidate any potential inhibition of PPB by $\mathrm{NH}_{4}{ }^{+}$or organic pollutants present in PWW. For this purpose, undiluted PWW and 5, 10 and 15 fold diluted (in tap water) piggery wastewaters were incubated with PPB for 20 days (final stationary phase of growth) as above described.

\subsubsection{Test series 2}

The influence of air dosing on PPB growth and carbon and nitrogen removal from PWW was evaluated in Test series 2 using 10 fold diluted PWW in order to assess the bioremediation potential of PPB under aerobic, microaerobic and anaerobic conditions. Two tests were performed under an open air atmosphere to maintain aerobic conditions with and without PPB inoculum. PWW biodegradation tests inoculated with PPB under 
a He atmosphere were also carried out with and without a periodic injection of $20 \mathrm{~mL}$ of air every two days. The tests were incubated for 20 days.

\subsubsection{Test series 3}

The influence of the addition of $\mathrm{CO}_{2}$ and $\mathrm{NaHCO}_{3}$ on PPB growth and carbon and nitrogen removal from PWW was evaluated in Test series 3 using 10 fold diluted PWW in order to elucidate the enhancement in the bioremediation potential of PPB mediated by an external $\mathrm{CO}_{2}$ addition. PWW treatment by PPB was evaluated under a $\mathrm{He}$ atmosphere in tests supplied every two days with $25 \mathrm{~mL}$ of pure $\mathrm{CO}_{2}(\geq 99.9 \%)$ or with $1 \mathrm{~mL}$ of $\mathrm{NaHCO}_{3}\left(8 \mathrm{~g} \mathrm{~L}^{-1}\right)$. A control test inoculated with PPB and incubated without $\mathrm{CO}_{2}$ or $\mathrm{NaHCO}_{3}$ addition was also carried out. By day 22, $1 \mathrm{~mL}$ of trace elements solution (López et al., 2018) was supplied to the control PPB test in order to assess if PWW treatment was limited by trace metal availability.

\subsubsection{Test series 4}

The influence of $\mathrm{pH}$ and $\mathrm{pH}$ control strategy on PPB growth and carbon and nitrogen removal from PWW was evaluated in Test series 4 using 10 fold diluted PWW in order to elucidate whether the beneficial effect of $\mathrm{CO}_{2}$ was due to its role as electron donor or to its contribution to maintain the pH low. PWW treatment by PPB was evaluated under a $\mathrm{He}$ atmosphere in tests supplied every two days with $25 \mathrm{~mL}$ of pure $\mathrm{CO}_{2}(\geq 99.9 \%)$, with $\mathrm{HCl}$ in order to match the $\mathrm{pH}$ of the $\mathrm{CO}_{2}$ supplemented tests and with $\mathrm{HCl}$ in order to maintain the $\mathrm{pH}$ at 7 . A control test inoculated with $\mathrm{PPB}$ and incubated without $\mathrm{CO}_{2}$ or $\mathrm{HCl}$ addition was also carried out.

\subsection{Analytical methods}


193 Dissolved TOC, TC, IC and TN concentrations were analyzed using a TOC-VCSH 194 TOC analyzer (Shimadzu, Japan) equipped with a TNM-1 unit. VFAs concentrations 195 were determined in a 7820A gas chromatograph (GC) equipped with a FID detector 196 (Agilent, USA) as described elsewhere (López et al., 2018). Samples for TOC/TN and 197 VFAs analyses were centrifuged at $10000 \mathrm{rpm}$ for $10 \mathrm{~min}$. The spectrum of absorbance 198 of PPB culture broth samples was analysed in a UV-2550 spectrophotometer 199 (Shimadzu, Japan) in the range at $350-850 \mathrm{~nm}$. Gas concentration of $\mathrm{CO}_{2}, \mathrm{H}_{2} \mathrm{~S}$ and $\mathrm{CH}_{4}$ in the headspace of the bottles was determined using a CP-3800 GC equipped with a TCD detector (Varian, USA) according to García et al. (2019). A pH 510 pHmeter

202 (Cyberscan, Netherlands) was used for $\mathrm{pH}$ determination. Finally, the quantification of TSS concentration was performed at the beginning and end of each test series according to Standard Methods (APHA, 2005).

\subsection{Statistical analysis}

The mean and standard deviations were calculated for duplicate bottles. Statistical analysis was performed by analysis of variance (ANOVA), followed by Tukey tests to identify the significance of the data obtained using Statgraphics Centurion software version 18. Comparisons with a value of $p<0.05$ were considered significant.

\section{Results and Discussion}

\subsection{Influence of the PWW load}

PPB were only able to grow in 5, 10 and 15 fold diluted piggery wastewaters as shown by the increase in $\mathrm{OD}_{808}$ over the 20 days of experiment (Fig. 1A). Biomass growth mainly occurred during the first 10 days. A limited PPB growth was observed in undiluted PWW likely due to the high $\mathrm{NH}_{4}{ }^{+}$concentrations present in the PWW (Getha 
et al., 1998) and to the fact that PPBs are not able to compete with chemotrophic bacteria as a result of the limited availability of light (Siefert et al., 1978). Indeed, photosynthesis and consequently the production of ATP for the photoassimilation of organic/inorganic compounds, are negatively affected in high turbidity media. The control tests (non-inoculated 10 fold diluted PWW) did not experience any significant increase in $\mathrm{OD}_{808}$ along the 20 days of experiment. Similarly, an increase in biomass concentrations (estimated by the difference between the final and initial TSS in the cultivation broth) of $0.72 \pm 0.17,0.74 \pm 0.08$ and $0.57 \pm 0.04 \mathrm{~g} \mathrm{TSS} \mathrm{L}^{-1}$ was recorded in g TSS $\mathrm{L}^{-1}$ in the undiluted PWW and control tests (Fig. 2A). The lower biomass concentration recorded in 15 fold diluted PWW was likely due to the lower concentration of biodegradable carbon and the high $\mathrm{pH}$ value in the cultivation broth of this test (as latter described in the sections below).

TOC removal efficiencies (REs) of $25 \pm 4 \%, 29 \pm 1 \%$ and $34 \pm 3 \%$ were achieved in 5 , 10 and 15 fold diluted tests, respectively, after 20 days of experiment (Fig. 1B). Organic carbon removal was correlated with biomass growth, and mainly occurred during the first 10 days, which suggests the assimilatory nature of TOC removal mechanisms. The rapid decrease in TOC concentration observed in tests with raw PWW (absence of significant biomass growth) and 5 fold diluted PWW during the first 6 days (Fig. 1B) was attributed to an experimental error during the first three samplings, where part of the organic matter pelletized after centrifugation was resuspended. Negligible variations in TOC concentrations of $5.8 \pm 0.4 \%$ were recorded in the control test. PPBs encode a large number of metabolic pathways and can degrade multiple carbon sources such as 
small molecules of fatty acids, alcohols, carbohydrates and a limited number of amino acids (Hülsen et al., 2018a; Lu et al., 2019b). More specifically, Rhodopseudomonas palustris has the complete tricarboxylic acid cycle (TCA), the Embden-Meyerhof pathway and the pentose phosphate pathway (Larimer et al., 2004). Under anaerobic conditions and infrared radiation supply, the anoxygenic photosynthesis would generate the energy necessary for the degradation of organic pollutants. This explains the rapid assimilation of TOC observed during the first days of the experiment.

Final TN removals of $14 \pm 5 \%, 18 \pm 2 \%$ and $21 \pm 1 \%$ were recorded in 5,10 and 15 fold diluted tests, respectively. These removals were also correlated with biomass growth and TOC removal, which confirms the assimilatory nature of the nitrogen removal mechanisms. In this context, PPBs are capable of assimilating all forms of nitrogen $\left(\mathrm{NO}_{3}{ }^{-}, \mathrm{NO}_{2}{ }^{-}, \mathrm{NH}_{4}{ }^{+}, \mathrm{N}_{2}\right.$ and organic $\left.\mathrm{N}\right)$, with confer these microorganisms a high potential for wastewater bioremediation ( $\mathrm{Lu}$ et al., 2019b). The elemental composition of PPBs cells in terms of $\mathrm{C}, \mathrm{N}, \mathrm{H}$ and $\mathrm{O}$ typically accounts for $52 \%, 11 \%$, $8 \%$ and $29 \%$, respectively, with a carbon:nitrogen $(\mathrm{C}: \mathrm{N})$ ratio of 5:1 (Carlozzi et al., 2006). In this context, the ratio of $\mathrm{C}: \mathrm{N}$ removed from PWW was 5:1 in PPB tests conducted with 10 or 15 folds diluted PWW (478 mg C removed:95 mg N removed; $381 \mathrm{mg} \mathrm{C}$ removed:75 $\mathrm{mg} \mathrm{N}$ removed). Therefore, all $\mathrm{C}$ and $\mathrm{N}$ removed was used for microbial growth (assimilative removal). Negligible nitrogen removal efficiencies ( $1 \%$ TN REs) were observed in the control test in the absence of PPB. On other hand, the $\mathrm{pH}$ increased from 8.00 at the beginning of the tests, up to $8.55 \pm 0.13,8.84 \pm 0.06$ and $8.92 \pm 0.14$ in the 5,10 and 15 fold diluted tests, and remained stable in undiluted and control tests (Fig. S3A). This increase in the $\mathrm{pH}$ of the culture broth was likely due to the consumption of organic acids and $\mathrm{CO}_{2}$ by PPB (Hülsen et al., 2014). 
$267 \mathrm{CO}_{2}$ concentration decreased in the headspace of the batch photobioreactors where PPB growth occurred. Thus, a decrease in $\mathrm{CO}_{2}$ concentrations from $31.4 \pm 3.2$ to $14.6 \pm 5.2 \mathrm{~g}$ $\mathrm{m}^{-3}$ was recorded in 5 fold diluted tests, while an almost complete $\mathrm{CO}_{2}$ depletion occurred in the headspace of the tests conducted with 10 and 15 fold diluted PWW (Fig. S4A1). This can be explained by anaerobic carbon fixation by PPB in the presence of

272 infrared light and by the increase in the $\mathrm{pH}$ of the cultivation broth (which mediated $273 \mathrm{CO}_{2}$ absorption by the culture medium). $\mathrm{CO}_{2}$ concentration in the headspace of undiluted PWW tests increased from $113 \pm 1$ to $241 \pm 13 \mathrm{~g} \mathrm{~m}^{-3}$ and from $20.5 \pm 0.8$ to $30.8 \pm 1.2 \mathrm{~g} \mathrm{~m}^{-3}$ in the control test, as a result of organic matter oxidation. On the other hand, $\mathrm{H}_{2} \mathrm{~S}$ concentration only increased in undiluted and 5 fold diluted tests up to $7.1 \pm$ 2.6 and $1.5 \pm 0.4 \mathrm{~g} \mathrm{~m}^{-3}$, respectively, which was likely due to sulphate reduction during anaerobic TOC oxidation. Finally, $\mathrm{CH}_{4}$ concentration increased in undiluted, 5 and 10 fold diluted tests up to $1.3 \pm 0.0,11.5 \pm 0.2$ and $4.0 \pm 1.9 \mathrm{~g} \mathrm{~m}^{-3}$. Interestingly, the higher concentration of $\mathrm{CH}_{4}$ (produced from the anaerobic digestion of TOC) was recorded in 5 fold diluted PWW, where methanogenesis was not likely inhibited by the high $\mathrm{NH}_{4}{ }^{+}$ concentrations present in raw PWW (Nakakubo et al., 2008; Yenigün and Demirel, 2013). A gradual development of anaerobic communities in 5 fold diluted tests was likely to occur since genes related to classical metabolic pathways for the generation of $\mathrm{CH}_{4}$ and $\mathrm{H}_{2} \mathrm{~S}$ in $R$. palustris have not been described in literature (Larimer et al., 2004). to the decrease in the inhibition effect by high concentrations of $\mathrm{NH}_{4}{ }^{+}$. Ten fold diluted PWW was selected for further experiments based on the similar biomass production compared to 5 fold dilution, the absence of $\mathrm{H}_{2} \mathrm{~S}$ generation, along with TOC and TN removals comparable to those achieved in 15 fold diluted tests. 
PPB were able to grow regardless of the extent of air supply as shown by the increase in

$\mathrm{OD}_{808}$ (Fig. 3A). However, a decrease in the absorbance in the tests inoculated with

PPB under an open atmosphere was observed from the day 8 onward. This decrease was due to the depletion of the carbon source as described below. Thus, an increase in TSS concentration (estimated as the difference between the final and initial biomass concentrations) of $0.43 \pm 0.01 \mathrm{~g} \mathrm{~L}^{-1}$ was recorded in aerated PPB tests, which was significantly lower than the biomass production at the end of the tests with PPB under a He atmosphere $\left(1.31 \pm 0.07 \mathrm{~g} \mathrm{~L}^{-1}\right)$ and with PPB periodically supplied with $20 \mathrm{~mL}$ of air conditions, although PPB growth is favored under anaerobic conditions in the presence of infrared radiation. Hence, phototrophic growth is favored under anaerobic conditions, in the absence of the inhibition of bacteriochlorophyll synthesis induced by oxygen but under chemotrophic growth. Finally, $\mathrm{OD}_{808}$ remained constant over time in the control tests, although PPB may naturally acclimate and grow under longer periods of time due to the intrinsic presence of these bacteria in wastewaters (García et al., 2019; Hülsen et al., 2014; Siefert et al., 1978).

TOC-REs of $37 \pm 3 \%$ and $41 \pm 2 \%$ were obtained in tests inoculated with PPB incubated under a $\mathrm{He}$ atmosphere and with periodic air supplementation, respectively (Fig. 3B). The slightly higher TOC-REs in the presence of $\mathrm{O}_{2}$ suggests that the contribution of the oxidative phosphorylation of PPB is promoted under micro-aerobic conditions ( $\mathrm{Lu}$ et al., 2011; Meng et al., 2017). PWW treatment under an open 
atmosphere resulted in an increase in TOC-REs up to $83 \pm 2 \%$ and $83 \pm 3 \%$ in tests inoculated with PPB and without inoculation, respectively, although TOC removal was initially faster in tests inoculated with PPB, which are known to aerobically assimilate organic matter. On the other hand, the degradation of VFAs was correlated to TOC removal (Fig. 3C, plotted as the carbon contained in all VFAs). Indeed, VFA-REs of 47 $\pm 15 \%$ and $45 \pm 11 \%$ were recorded in PPB tests conducted under a He atmosphere without and with addition of air, respectively. This partial assimilation of VFAs was likely due to both the lack of electron acceptor in the cultivation broth and the inhibition mediated by the increase in $\mathrm{pH}$. A negligible degradation of VFAs was recorded in the control tests, while high VFA-REs of $83 \pm 1 \%$ and $90 \pm 7 \%$ were achieved in the open photobioreactors with and without PPB inoculation, respectively. Interestingly, the high TOC and VFA removals in the non-inoculated aerobic PWW biodegradation tests entailed a decrease in the final TSS concentration (Fig. 2), which confirmed the absence of growth of chemotrophic bacteria (described as bacteria with an efficient fermentative were the main substrate of PPB. Interestingly, the occurrence of aerobic conditions out in the open photobioreactors. VFA depletion by day 8 in open photobioreactors inoculated with PPB correlated with the decline in $\mathrm{OD}_{808}$, which confirmed that VFAs during PWW degradation did not increase PPB growth, but resulted in significant carbon losses. Hence $133 \pm 10 \%, 87 \pm 5 \%$ and $19 \pm 0 \%$ of the carbon removed was recovered in the form of biomass in the tests conducted with PPB under a He atmosphere, with periodic air supplementation and under an open atmosphere, respectively. The high carbon recovery under a He atmosphere was likely due to an experimental error in the determination of biomass concentration. VFAs mixtures support superior PPB growth rates compared to individual VFA solutions, propionic 
acid being the preferred VFA by PPB (Alloul et al., 2019). Indeed, propionic acid was completely consumed in all tests inoculated with PPB. Moreover, VFAs can be metabolized by VFA catabolic pathways and converted into Acetyl-CoA for subsequent degradation in the TCA cycle in PPB.

TN-REs of $29 \pm 3 \%, 33 \pm 1 \%, 32 \pm 1 \%$ and $12 \pm 1 \%$ were recorded in tests inoculated with PPB under a He atmosphere, with periodic air dosing, under an open atmosphere and in non-inoculated tests in open photobioreactors, respectively (Fig. 3D). A low TNREs of $4.8 \pm 0.1 \%$ was recorded in the control test with PWW under a He atmosphere. The absence of biomass growth in non-inoculated tests in open photobioreactors suggests that $\mathrm{TN}$ removal was due to $\mathrm{NH}_{4}{ }^{+}$volatilization, while nitrogen assimilation into biomass (i.e. protein formation) was the main mechanism in enclosed photobioreactors. Overall the TN recovered in the form of biomass decreased from 101 $\pm 13 \%$ to $64 \pm 0 \%$ and $26 \pm 1 \%$ under periodic $\mathrm{O}_{2}$ dosing or open photobioreactors. PPB can support an efficient assimilation of TN in domestic wastewater treatment (Hülsen et al., 2014), with $99.6 \% \mathrm{~N}$ removal efficiencies under anaerobic conditions and infrared radiation, but domestic wastewater presents lower concentrations of nitrogen $(46 \mathrm{mg}$ $\left.\mathrm{NH}_{4}-\mathrm{N} \mathrm{L}^{-1}\right)$ compared to 10 fold diluted PWW $\left(503 \pm 33.9 \mathrm{mg} \mathrm{N} \mathrm{L}^{-1}\right)$. Therefore, this study showed that PPBs can grow at high nitrogen concentrations, and agree with literature studies that reported growth of pure cultures of PPB at $650 \mathrm{mg} \mathrm{NH}_{4} \mathrm{Cl} \mathrm{L}^{-1}$ (Carlozzi and Sacchi, 2001) or up to $8000 \mathrm{mg} \mathrm{N} \mathrm{L}^{-1}$ (Meng et al., 2018). Unfortunately, only the final $\mathrm{pHs}$ were recorded in this test due to a failure in the $\mathrm{pH}$ electrode. Thus, $\mathrm{pH}$ values of $7.89 \pm 0.02,9.51 \pm 0.08$ and $9.38 \pm 0.07$ were recorded in the control test, in the test inoculated with PPB under a He atmosphere and with periodic dosing of air, respectively, while $\mathrm{pH}$ of $9.03 \pm 0.09$ and $8.93 \pm 0.20$ were recorded in the open tests with and without PPB inoculation, respectively. 
$366 \mathrm{CO}_{2}$ concentration in the headspace of the photobioreactors was depleted in all closed

367 tests except the control, where an increase from $12.2 \pm 0.3$ to $26.7 \pm 1.5 \mathrm{~g} \mathrm{~m}^{-3}$ was 368 observed (Fig. S4A2). Finally, the presence of $\mathrm{H}_{2} \mathrm{~S}$ and $\mathrm{CH}_{4}$ was not detected in the 369 headspace of the photobioreactors during the course of this experiment (Fig. S4B2, 370 S4C2).

371 PPBs are photoheterotrophs and the presence of oxygen in the cultivation broth is 372 known to inhibit the synthesis of bacteriochlorophyll (Izu et al., 2001). However, recent studies have reported that microaerophilic conditions during PPB cultivation can 374 substantially improve the efficiency of PPB-based wastewater treatment in 375 photobioreactors operated with mixed cultures (Lu et al., 2019a; Peng et al., 2018; Yang et al., 2018). Under microaerophilic conditions it is very likely that aerobic organisms co-exist together with PPBs, which allows to anticipate that a symbiosis between PPBs and heterotrophic aerobes can be beneficial in photobioreactors devoted to wastewater treatment, provided that the Redox potential is maintained in negative values (Siefert et al., 1978).

In brief, PPBs were able to assimilate carbon/nutrients and grow both anaerobically and aerobically, which confirms their high metabolic plasticity. A photoautotrophic metabolism based on the fixation of $\mathrm{CO}_{2}$ and energy obtained from photosynthesis was initially observed, with a gradual contribution of a photoheterotrophic metabolism in the tests under a Helium atmosphere. Under an air atmosphere, a large fraction of the organic matter was removed via volatilization since the amount of biomass produced did not correlate with TOC or VFA degradation. In PPB-Air, the high organic matter content at the early stages of biodegradation favored anaerobic conditions and promoted PPB growth (as indicated by the increase in $\mathrm{OD}_{808}$ ), while bacteriochlorophyll synthesis 
was inhibited in the presence of oxygen at the latest stages of the test, when VFA were depleted.

The feasibility of scaling wastewater treatment with PPB in photoanaerobic systems is under investigation at semi-industrial scale within the first photobiorefinery in Europe, constructed in the framework of the BBI-H2020 Deep Purple project focused on the extraction and recovery of high value-added resources with PPB (https://deeppurple.eu/).

\subsection{Influence of $\mathrm{CO}_{2}$ and $\mathrm{NaHCO}_{3}$ on $\mathrm{PPB}$ growth and nutrient recovery}

The growth of PPB was significantly favored by the addition of $\mathrm{CO}_{2}$ to the photobioreactor headspace (Fig. 4A). Thus, the $\mathrm{OD}_{808}$ in the test inoculated with PPB and supplemented with $\mathrm{CO}_{2}$ increased by $80 \%$ compared to the tests without $\mathrm{CO}_{2}$ addition. Interestingly, $\mathrm{NaHCO}_{3}$ addition did not result in a significant increase or decrease in PPB growth. The increase in TSS concentrations (estimated as the difference between the final and initial biomass concentrations) accounted for $1.00 \pm$ 0.06, $1.81 \pm 0.07$ and $1.09 \pm 0.13 \mathrm{~g} \mathrm{~L}^{-1}$ for PPB, $\mathrm{PPB}$ with $\mathrm{CO}_{2}$ addition and $\mathrm{PPB}$ with $\mathrm{NaHCO}_{3}$ addition, respectively, which confirmed the beneficial effect of $\mathrm{CO}_{2}$ addition (Fig. 2C). The supplementation of trace elements by day 22 did not result in an enhancement of PPB growth and revealed that PWW biodegradation was not limited by essential micronutrients.

$<$ Figure 4>

Removal efficiencies of TOC of $31 \pm 0 \%$ and $36 \pm 1 \%$ were achieved in tests with PPB and PPB with $\mathrm{NaHCO}_{3}$ addition, respectively (Fig. 4B). A significant increase in TOC RE up to $72 \pm 3 \%$ was recorded when PPB were supplemented with $\mathrm{CO}_{2}$, which was 
414 initially attributed to the beneficial effect of $\mathrm{CO}_{2}$ as electron acceptor. The enclosed 415 nature of the experimental set-up entails that TOC removal was caused by carbon 416 assimilation into PPB biomass. No significant variation in TOC concentration 417 throughout the experiment was observed in the control tests. Similarly, VFA-REs of 26 $418 \pm 3 \%, 74 \pm 13 \%$ and $26 \pm 16 \%$ were achieved in tests with PPB, PPB with $\mathrm{CO}_{2}$ addition 419 and PPB with $\mathrm{NaHCO}_{3}$ addition, respectively (Fig. 4C). The lag phase in VFA 420 consumption initially observed in Figure 4C was due to the preferential assimilation of highly reduced soluble organic compounds (not determined in this study) present in PWW. On the other hand, negligible variations in VFA concentration were recorded in 423 the control tests, which agreed with TOC measurements.

424 Final TN removals of $15 \pm 2 \%, 33 \pm 3 \%$ and $21 \pm 1 \%$ were recorded in tests with PPB, PPB with $\mathrm{CO}_{2}$ addition and PPB with $\mathrm{NaHCO}_{3}$ addition, respectively. The superior removal of TN mediated by $\mathrm{CO}_{2}$ supplementation correlated with the growth of PPB 427 and TOC removal, and points out toward assimilation as the main nitrogen removal 428 mechanisms. On other hand, $\mathrm{pH}$ values increased from $8.08 \pm 0.07$ to $8.80 \pm 0.03$ and $8.91 \pm 0.15$ in tests with PPB and PPB with $\mathrm{NaHCO}_{3}$ addition, respectively (Fig. S3B), while $\mathrm{CO}_{2}$ addition maintained the $\mathrm{pH}$ stable at $8.12 \pm 0.00$ (as a result of the acidification caused of this gas), values similar to those recorded in the control test $(8.18 \pm 0.00)$.

All $\mathrm{CO}_{2}$ concentration initially present in the headspace of the photobioreactors was absorbed in the tests with PPB and PPB with $\mathrm{NaHCO}_{3}$ addition $\left(1.7 \pm 0.2 \mathrm{~g} \mathrm{~m}^{-3}\right)$ despite TOC mineralization, which highlights the key role of the $\mathrm{pH}$ increase in $\mathrm{CO}_{2}$ sequestration. The concentration of $\mathrm{CO}_{2}$ in the $\mathrm{PPB}$ test supplemented with $\mathrm{CO}_{2}$ 437 remained stable for the first 8 days (when $\mathrm{pH}$ increased) and increased approximately by $34.4 \pm 11.8 \mathrm{~g} \mathrm{~m}^{-3}$ every two days afterwards (Fig. S4A3). An increase in $\mathrm{CO}_{2}$ 
concentration up to $41.4 \pm 1.5 \mathrm{~g} \mathrm{~m}^{-3}$ was recorded in the control tests concomitantly

440 with an increase in $\mathrm{H}_{2} \mathrm{~S}$ concentration up to $4.49 \pm 0.16 \mathrm{~g} \mathrm{~m}^{-3}$ from day 14 , which was 441 mediated by sulphate reducing bacteria oxidizing a fraction of the VFAs. $\mathrm{H}_{2} \mathrm{~S}$ and $\mathrm{CH}_{4}$ 442 were not detected in the headspace of the photobioreactors inoculated with PPB.

443 A sequence of photoheterotrophic metabolic routes was hypothesized in test performed with PPB and $\mathrm{CO}_{2}$ addition, where photoheterotrophy of non-VFA reduced organic substrates occurred in the first 8 days. This was evidenced by the consumption of a fraction of TOC, while VFA concentrations remained constant. In addition, an intensive usage of $\mathrm{CO}_{2}$ occurred in the initial stages of PWW biodegradation to support reduced organics assimilation by directing the excess of reductive power through the Calvin Cycle (McKinlay and Harwood, 2010). After 8 days, the phototrophic consortia started to assimilate VFAs at high uptake rates (Fig. 4C), concomitantly with an increase in $\mathrm{CO}_{2}$ headspace concentration without a significant increase in the $\mathrm{pH}$ of the cultivation broth. This confirmed the beneficial role of $\mathrm{CO}_{2}$ addition on PPB mediated PWW treatment.

\subsection{Influence of pH on PPB growth and nutrient recovery}

PPB growth in tests supplemented with $\mathrm{CO}_{2}$ and with $\mathrm{pH}$ control at 7 was very similar (Fig. 5A). The $\mathrm{OD}_{808}$ of the PPB culture without $\mathrm{pH}$ control or $\mathrm{CO}_{2}$ addition increased up 1.25, values similar to those obtained in previous tests. Likewise, the control tests did not experience any significant increase in $\mathrm{OD}_{808}$ along the 34 days of experiment.

460 Final biomass productions (estimated as the difference between the final and initial 461 TSS) of $0.83 \pm 0.21,1.65 \pm 0.30,1.58 \pm 0.04$ and $2.00 \pm 0.14 \mathrm{~g} \mathrm{TSS} \mathrm{L}^{-1}$ were recorded 462 in tests with $\mathrm{PPB}, \mathrm{PPB}$ with $\mathrm{CO}_{2}$ addition, $\mathrm{PPB}$ with $\mathrm{pH}$ controlled to maintain similar 
values to the test with $\mathrm{CO}_{2}$ addition and $\mathrm{PPB}$ with $\mathrm{pH}$ control at 7 , respectively. These results clearly demonstrated the prominent role of $\mathrm{pH}$ on PPB growth under these experimental conditions.

$<$ Figure 5>

TOC removal efficiencies of $30 \pm 1 \%, 69 \pm 3 \%, 58 \pm 2 \%$ and $75 \pm 2 \%$ were achieved in tests with $\mathrm{PPB}, \mathrm{PPB}$ with addition of $\mathrm{CO}_{2}$, $\mathrm{PPB}$ with $\mathrm{pH}$ controlled to maintain similar values to the test with $\mathrm{CO}_{2}$ addition and $\mathrm{PPB}$ with $\mathrm{pH}$ control at 7 , respectively. Similarly, the degradation of VFAs also occurred with efficiencies $49 \pm 1 \%, 92 \pm 3 \%$, $77 \pm 1 \%$ and $98 \pm 1 \%$. The highest removals of TOC and VFA were obtained in the PPB tests with $\mathrm{pH}$ maintained at 7 . These removals were significantly higher than those recorded in the tests with addition of $\mathrm{CO}_{2}$ and with $\mathrm{pH}$ controlled to maintain similar values, thus confirming the key role of $\mathrm{pH}$ on organic matter removal by PPB during PWW treatment. VFAs are the main constituent of PWW organic matter, representing $80 \%$ of the carbon present in this type of wastewater $\left(1.2 \mathrm{gVFAs}(\mathrm{C}) \mathrm{L}^{-1}\right.$ versus 1.5 gTOC $\mathrm{L}^{-1}$ ). It has been consistently described in literature that PPBs are capable of assimilating a large number of VFAs as a carbon source (Wei et al., 2016), while some species such as Rhodopseudomonas have the ability to use all short-chain VFAs (C2C6) in comparison to Rhodobacter (Okubo et al., 2005). A large concentration of VFAs can result in inhibition of PPB growth (Ghosh et al., 2017), while the consumption of VFAs mediates an increase in $\mathrm{pH}$ due to the acidic nature of these compounds, which might ultimately inhibit PPB growth.

Final TN removals of $25 \pm 3 \%, 38 \pm 4 \%, 34 \pm 4 \%$ and $39 \pm 3 \%$ were recorded in tests with PPB, PPB with addition of $\mathrm{CO}_{2}$, PPB with $\mathrm{pH}$ controlled to maintain similar values to the test with $\mathrm{CO}_{2}$ addition and PPB with $\mathrm{pH}$ control at 7 , respectively. Negligible variations in TN concentration were recorded in the control test with PWW under a He 
atmosphere. The highest TN removal was obtained in the PPB test with $\mathrm{pH}$ adjusted to 7, condition supporting also the highest biomass production and TOC removal. The values of $\mathrm{pH}$ increased from $7.96 \pm 0.02$ to $8.87 \pm 0.27$ in the PPB test without $\mathrm{pH}$ control or $\mathrm{CO}_{2}$ addition, and from $7.46 \pm 0.02$ to $7.94 \pm 0.04$ in PPB tests with addition of $\mathrm{CO}_{2}$. The benefits derived from $\mathrm{CO}_{2}$ addition were induced by the indirect $\mathrm{pH}$ control exerted in the cultivation broth, which showed an optimum performance at $\mathrm{pH}$. The optimal $\mathrm{pH}$ range described for $R$. palustris is 6-8.5 (van Niel, 1944), with bacterial growth inhibition occurring at higher $\mathrm{pH}$ values. PPB inhibition at high $\mathrm{pH}$ values was likely due to the loss of the electrochemical potential between the cultivation medium and the cytoplasm, which decreases the proton motive force necessary for the synthesis of ATP by ATP-synthase during photosynthesis.

The $\mathrm{CO}_{2}$ concentration present in the photobioreactor headspace was absorbed in the tests with PPB (Fig. S4A4). No significant variations were observed in the tests with PPB with $\mathrm{pH}$ controlled to maintain similar values to the test with $\mathrm{CO}_{2}$ addition and control test, where $\mathrm{CO}_{2}$ concentrations remained constant at $10.9 \pm 4.2$ and $23.9 \pm 2.5 \mathrm{~g}$ $\mathrm{m}^{-3}$, respectively. An increase in $\mathrm{CO}_{2}$ concentration was recorded in the test with $\mathrm{CO}_{2}$ addition from day 10 onwards and in the tests with $\mathrm{pH} 7$ from day 20 onwards. The increase in the concentration of $\mathrm{CO}_{2}$ observed in the test with $\mathrm{pH}$ control at 7, was likely due to the swift in the metabolism of PPB form a carbon assimilatory to a dissimilatory metabolism. Neither $\mathrm{H}_{2} \mathrm{~S}$ nor $\mathrm{CH}_{4}$ were detected in the headspace of the photobioreactors during the course of this experiment regardless of the conditions tested.

In brief, phototrophic metabolism was highly efficient for the treatment of PWW under neutral $\mathrm{pH}$. Similarly, empirically validated simulations of $R$. palustris metabolism under anaerobic conditions with acetate in minimal media resulted in an increase in $\mathrm{pH}$, 
513 which confirms that proton metabolism plays a key role for optimal growth in PPB

514 (Navid et al., 2019).

\section{Conclusions}

517 PWW treatment using mixed cultures of PPB under infrared radiation represents a 518 promising platform for resource recovery under optimized operational conditions. 519 PWW dilution is required to prevent the inhibition of PPB as a result of the high 520 strength of this wastewater. Resource recovery using PPB seems to be hindered by the 521 presence of air. $\mathrm{CO}_{2}$ addition was identified as an effective operational strategy to maximize carbon and nitrogen removal from PWW along with PPB growth. However, the beneficial effects from $\mathrm{CO}_{2}$ supplementation derived from $\mathrm{pH}$ control, which is the actual key control parameter on PPB-based PWW valorization.

Acknowledgements

527 The financial support from the Regional Government of Castilla y León, the EU528 FEDER programme (CLU 2017-09 and UIC 071) and CONICYT (PFCHA/DOCTORADO BECAS CHILE/2017 - 72180211) is gratefully acknowledged. The authors also thank Enrique Marcos and Beatriz Muñoz for their technical assistance in the TOC/VFAs analysis and calibration of materials used, respectively.

534 Supplementary Materials: Figure S1: Absorption spectrum (350-850 nm) of PWW 535 and PPB in 10 fold diluted PWW at the beginning and end of the assay (Test series 1).

536 Figure S2: Photograph of the experimental set-up with photobioreactors with PWW 537 diluted 10 fold (left) and bottles inoculated with PPB in 10 fold diluted PWW (right) 
under a He atmosphere. Figure S3: Trend of $\mathrm{pH}$ during PWW biodegradation in Test series 1 (A), Test series 3 (B) and Test series 4 (C). Figure S4: Trend of the gas concentration of $\mathrm{CO}_{2}$ (A), $\mathrm{H}_{2} \mathrm{~S}$ (B) and $\mathrm{CH}_{4}$ (C) in the headspace of the photobioreactors in Test series 1 (1), Test series 2 (2), Test series 3 (3) and Test series 4 (4).

\section{References}

Alloul, A., Wuyts, S., Lebeer, S., Vlaeminck, S.E., 2019. Volatile fatty acids impacting phototrophic growth kinetics of purple bacteria: Paving the way for protein production on fermented wastewater. Water Res. 152, 138-147. https://doi.org/10.1016/J.WATRES.2018.12.025

APHA, 2005. Standard Methods for the Examination of Water and Wastewater, 21st ed. American Public Health Association, Washington, DC, USA.

Carlozzi, P., Pushparaj, B., Degl'Innocenti, A., Capperucci, A., 2006. Growth characteristics of Rhodopseudomonas palustris cultured outdoors, in an underwater tubular photobioreactor, and investigation on photosynthetic efficiency. Appl. Microbiol. Biotechnol. 73, 789-795. https://doi.org/10.1007/s00253-006-0550-z

Carlozzi, P., Sacchi, A., 2001. Biomass production and studies on Rhodopseudomonas palustris grown in an outdoor, temperature controlled, underwater tubular photobioreactor. J. Biotechnol. 88, 239-249. https://doi.org/10.1016/S0168-

$$
1656(01) 00280-2
$$

Chen, G., Huang, J., Tian, X., Chu, Q., Zhao, Y., Zhao, H., 2018. Effects of influent loads on performance and microbial community dynamics of aerobic granular sludge treating piggery wastewater. J. Chem. Technol. Biotechnol. 93, 1443-1452. https://doi.org/10.1002/jctb.5512 
Dalaei, P., Ho, D., Nakhla, G., Santoro, D., 2019. Low temperature nutrient removal from municipal wastewater by purple phototrophic bacteria (PPB). Bioresour. Technol. 288, 121566. https://doi.org/10.1016/j.biortech.2019.121566

García, D., de Godos, I., Domínguez, C., Turiel, S., Bolado, S., Muñoz, R., 2019. A systematic comparison of the potential of microalgae-bacteria and purple phototrophic bacteria consortia for the treatment of piggery wastewater. Bioresour. Technol. 276, 18-27. https://doi.org/10.1016/J.BIORTECH.2018.12.095

Getha, K., Vikineswary, S., Chong, V.C., 1998. Isolation and growth of the phototrophic bacterium Rhodopseudomonas palustris strain B1 in sago-starchprocessing wastewater. World J. Microbiol. Biotechnol. 14, 505-511. https://doi.org/10.1023/A:1008855125634

Ghosh, S., Dairkee, U.K., Chowdhury, R., Bhattacharya, P., 2017. Hydrogen from food processing wastes via photofermentation using Purple Non-sulfur Bacteria (PNSB) - A review. Energy Convers. Manag. https://doi.org/10.1016/j.enconman.2016.09.001

Godos, I. de, Blanco, S., García-Encina, P.A., Becares, E., Muñoz, R., 2009. Long-term operation of high rate algal ponds for the bioremediation of piggery wastewaters at high loading rates. Bioresour. Technol. 100, 4332-4339. https://doi.org/10.1016/J.BIORTECH.2009.04.016

Godos, I. de, Vargas, V.A., Blanco, S., González, M.C.G., Soto, R., García-Encina, P.A., Becares, E., Muñoz, R., 2010. A comparative evaluation of microalgae for the degradation of piggery wastewater under photosynthetic oxygenation. Bioresour. Technol. 101, 5150-5158. https://doi.org/10.1016/J.BIORTECH.2010.02.010

Gordon, J.M., Polle, J.E.W., 2007. Ultrahigh bioproductivity from algae. Appl. 

Microbiol. Biotechnol. https://doi.org/10.1007/s00253-007-1102-X

Hülsen, T., Barry, E.M., Lu, Y., Puyol, D., Batstone, D.J., 2016a. Low temperature treatment of domestic wastewater by purple phototrophic bacteria: Performance, activity, and community. Water Res. 100, 537-545. https://doi.org/10.1016/J.WATRES.2016.05.054

Hülsen, T., Barry, E.M., Lu, Y., Puyol, D., Keller, J., Batstone, D.J., 2016b. Domestic wastewater treatment with purple phototrophic bacteria using a novel continuous photo anaerobic membrane bioreactor. Water Res. 100, 486-495. https://doi.org/10.1016/J.WATRES.2016.04.061

Hülsen, T., Batstone, D.J., Keller, J., 2014. Phototrophic bacteria for nutrient recovery from domestic wastewater. Water Res. 50, 18-26. https://doi.org/10.1016/J.WATRES.2013.10.051

Hülsen, T., Hsieh, K., Batstone, D.J., 2019. Saline wastewater treatment with purple phototrophic bacteria. Water Res. 160, 259-267. https://doi.org/10.1016/J.WATRES.2019.05.060

Hülsen, T., Hsieh, K., Lu, Y., Tait, S., Batstone, D.J., 2018a. Simultaneous treatment and single cell protein production from agri-industrial wastewaters using purple phototrophic bacteria or microalgae - A comparison. Bioresour. Technol. 254, 214-223. https://doi.org/10.1016/J.BIORTECH.2018.01.032

Hülsen, T., Hsieh, K., Tait, S., Barry, E.M., Puyol, D., Batstone, D.J., 2018b. White and infrared light continuous photobioreactors for resource recovery from poultry processing wastewater - A comparison. Water Res. 144, 665-676. https://doi.org/10.1016/J.WATRES.2018.07.040

Hunter, C.N., Daldal, F., Thurnauer, M.C., Beatty, J.T. (Eds.), 2009. The Purple Phototrophic Bacteria, Advances in Photosynthesis and Respiration. Springer 
Izu, K., Nakajima, F., Yamamoto, K., Kurisu, F., 2001. Aeration conditions affecting growth of purple nonsulfur bacteria in an organic wastewater treatment process. Syst. Appl. Microbiol. 24, 294-302. https://doi.org/10.1078/0723-2020-00027 Pelletier, D.A., Beatty, J.T., Lang, A.S., Tabita, F.R., Gibson, J.L., Hanson, T.E., Bobst, C., Torres, J.L.T. y, Peres, C., Harrison, F.H., Gibson, J., Harwood, C.S., 2004. Complete genome sequence of the metabolically versatile photosynthetic bacterium Rhodopseudomonas palustris. Nat. Biotechnol. 22, 55-61. https://doi.org/10.1038/nbt923

López, J.C., Arnáiz, E., Merchán, L., Lebrero, R., Muñoz, R., 2018. Biogas-based polyhydroxyalkanoates production by Methylocystis hirsuta: A step further in anaerobic digestion biorefineries. Chem. Eng. J. 333, 529-536. https://doi.org/10.1016/J.CEJ.2017.09.185

Lu, H., Peng, M., Zhang, G., Li, B., Li, Y., 2019a. Brewery wastewater treatment and resource recovery through long term continuous-mode operation in pilot photosynthetic bacteria-membrane bioreactor. Sci. Total Environ. 646, 196-205. https://doi.org/10.1016/j.scitotenv.2018.07.268

Lu, H., Zhang, G., Dong, S., 2011. Quantitative study of PNSB energy metabolism in degrading pollutants under weak light-micro oxygen condition. Bioresour. Technol. 102, 4968-4973. https://doi.org/10.1016/J.BIORTECH.2011.01.027

Lu, H., Zhang, G., Zheng, Z., Meng, F., Du, T., He, S., 2019b. Bio-conversion of photosynthetic bacteria from non-toxic wastewater to realize wastewater treatment and bioresource recovery: A review. Bioresour. Technol. 278, 383-399. https://doi.org/10.1016/J.BIORTECH.2019.01.070 
Madigan, M.T., Jung, D.O., Woese, C.R., Achenbach, L.A., 2000. Rhodoferax antarcticus sp. nov., a moderately psychrophilic purple nonsulfur bacterium isolated from an Antarctic microbial mat. Arch. Microbiol. 173, 269-277. https://doi.org/10.1007/s002030000140

McKinlay, J.B., Harwood, C.S., 2010. Carbon dioxide fixation as a central redox cofactor recycling mechanism in bacteria. Proc. Natl. Acad. Sci. U. S. A. 107, 11669-11675. https://doi.org/10.1073/pnas.1006175107

Meng, F., Yang, A., Zhang, G., Wang, H., 2017. Effects of dissolved oxygen concentration on photosynthetic bacteria wastewater treatment: Pollutants removal, cell growth and pigments production. Bioresour. Technol. 241, 993-997. https://doi.org/10.1016/j.biortech.2017.05.183

Meng, F., Zhang, G., Yang, A., Li, J., Zhang, Y., Zou, Z., Qian, X., 2018. Bioconversion of wastewater by photosynthetic bacteria: Nitrogen source range, fundamental kinetics of nitrogen removal, and biomass accumulation. Bioresour. Technol. Reports 4, 9-15. https://doi.org/10.1016/J.BITEB.2018.08.012

Nakakubo, R., Møller, H.B., Nielsen, A.M., Matsuda, J., 2008. Ammonia Inhibition of Methanogenesis and Identification of Process Indicators during Anaerobic Digestion. Environ. Eng. Sci. 25, 1487-1496. https://doi.org/10.1089/ees.2007.0282

Navid, A., Jiao, Y., Wong, S.E., Pett-Ridge, J., 2019. System-level analysis of metabolic trade-offs during anaerobic photoheterotrophic growth in Rhodopseudomonas palustris. BMC Bioinformatics 20, 233. https://doi.org/10.1186/s12859-019-2844-Z

Okubo, Y., Futamata, H., Hiraishi, A., 2005. Distribution and Capacity for Utilization of Lower Fatty Acids of Phototrophic Purple Nonsulfur Bacteria in Wastewater 

Environments. Microbes Environ. 20, 135-143. https://doi.org/10.1264/jsme2.20.135

Peng, M., Yang, A., Chen, Y., Zhang, G., Meng, F., Ma, X., Li, Y., 2018. Microbiology community changes during the start-up and operation of a photosynthetic bacteriamembrane bioreactor for wastewater treatment. Bioresour. Technol. Reports 1, 18. https://doi.org/10.1016/j.biteb.2018.01.003

Posten, C., Schaub, G., 2009. Microalgae and terrestrial biomass as source for fuels-A process view. J. Biotechnol. https://doi.org/10.1016/j.jbiotec.2009.03.015

Puyol, D., Barry, E.M., Hülsen, T., Batstone, D.J., 2017. A mechanistic model for anaerobic phototrophs in domestic wastewater applications: Photo-anaerobic model (PAnM). Water Res. 116, 241-253. https://doi.org/10.1016/J.WATRES.2017.03.022

Siefert, E., Irgens, R.L., Pfennig, N., 1978. Phototrophic purple and green bacteria in a sewage treatment plant. Appl. Environ. Microbiol. 35, 38-44.

Stomp, M., Huisman, J., Stal, L.J., Matthijs, H.C.P., 2007. Colorful niches of phototrophic microorganisms shaped by vibrations of the water molecule. ISME J. 1, 271-282. https://doi.org/10.1038/ismej.2007.59

Suwan, D., Chitapornpan, S., Honda, R., Chiemchaisri, C., 2014. Conversion of organic carbon in food processing wastewater to photosynthetic biomass in photobioreactors using different light sources. Environ. Eng. Res. 19, 293-298. https://doi.org/10.4491/eer.2014.S1.009

van Niel, C.B., 1944. The culture, general physiology, morphology, and classification of the non-sulfur purple and brown bacteria. Bacteriol. Rev. 8, 1-118.

Wei, H., Okunishi, S., Yoshikawa, T., Kamei, Y., Maeda, H., 2016. Isolation and Characterization of a Purple Non-Sulfur Photosynthetic Bacterium 
696

697

698

699

700

701

702

703

704

705

Rhodopseudomonas faecalis Strain A from Swine Sewage Wastewater. Biocontrol Sci. 21, 29-36. https://doi.org/10.4265/bio.21.29

Yang, A., Peng, M., Zhang, G., Meng, F., Zhang, Y., Zou, Z., 2018. Effects of lightoxygen conditions on microbial community of photosynthetic bacteria during treating high-ammonia wastewater. Process Biochem. 72, 137-142. https://doi.org/10.1016/j.procbio.2018.06.003

Yenigün, O., Demirel, B., 2013. Ammonia inhibition in anaerobic digestion: A review. Process Biochem. 48, 901-911. https://doi.org/10.1016/J.PROCBIO.2013.04.012

(1)

7

8

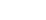




\section{List of figures}

707

708

Figure 1. Trend of culture absorbance (A), and TOC (B) and TN (C) concentrations

709 during piggery wastewater biodegradation by PPB in raw PWW ( $\Delta$ ) (secondary axis

710 values in gray), 5 times diluted PWW $(\diamond), 10$ times diluted PWW ( $\mathbf{\square}), 15$ times diluted 711 PWW (०) and non inoculated PWW (*).

713 Figure 2. Variation in TSS concentration during piggery wastewater biodegradation in test 1 (A), test 2 (B), test 3 (C) and test 4 (D). Values represented the difference between the final and initial TSS concentrations.

716

717 Figure 3. Trend of culture absorbance (A), and TOC (B), volatile fatty acid (C) and TN

(D) concentrations during 10 times diluted piggery wastewater biodegradation by PPB

(匹), PPB with air dosing $(\triangle)$ and non-inoculated PWW (*) in closed photobioreactors, and PWW biodegradation by PPB $(\diamond)$ and non-inoculated PWW (०) in open photobioreactors.

Figure 4. Trend of culture absorbance (A), and TOC (B), volatile fatty acids (C) and TN (D) concentrations during 10 times diluted piggery wastewater biodegradation by PPB (๘), PPB with $\mathrm{CO}_{2}$ supplementation ( $\left.\mathbf{\Delta}\right), \mathrm{PPB}$ with $\mathrm{NaHCO}_{3}$ supplementation $(\diamond)$ and non-inoculated PWW (*). 
728 Figure 5. Trend of culture absorbance (A), and TOC (B), volatile fatty acids (C) and 729 TN (D) concentration during 10 times diluted piggery wastewater biodegradation by 730 PPB ( $\square$ ), PPB with $\mathrm{CO}_{2}$ supplementation $(\triangle)$, PPB with $\mathrm{pH}$ controlled to maintain 731 similar values to the test with $\mathrm{CO}_{2}$ addition $(\diamond)$, PPB with $\mathrm{pH}$ control at 7 via $\mathrm{HCl}$ 732 addition $(\bullet)$ and non-inoculated PWW (*). 

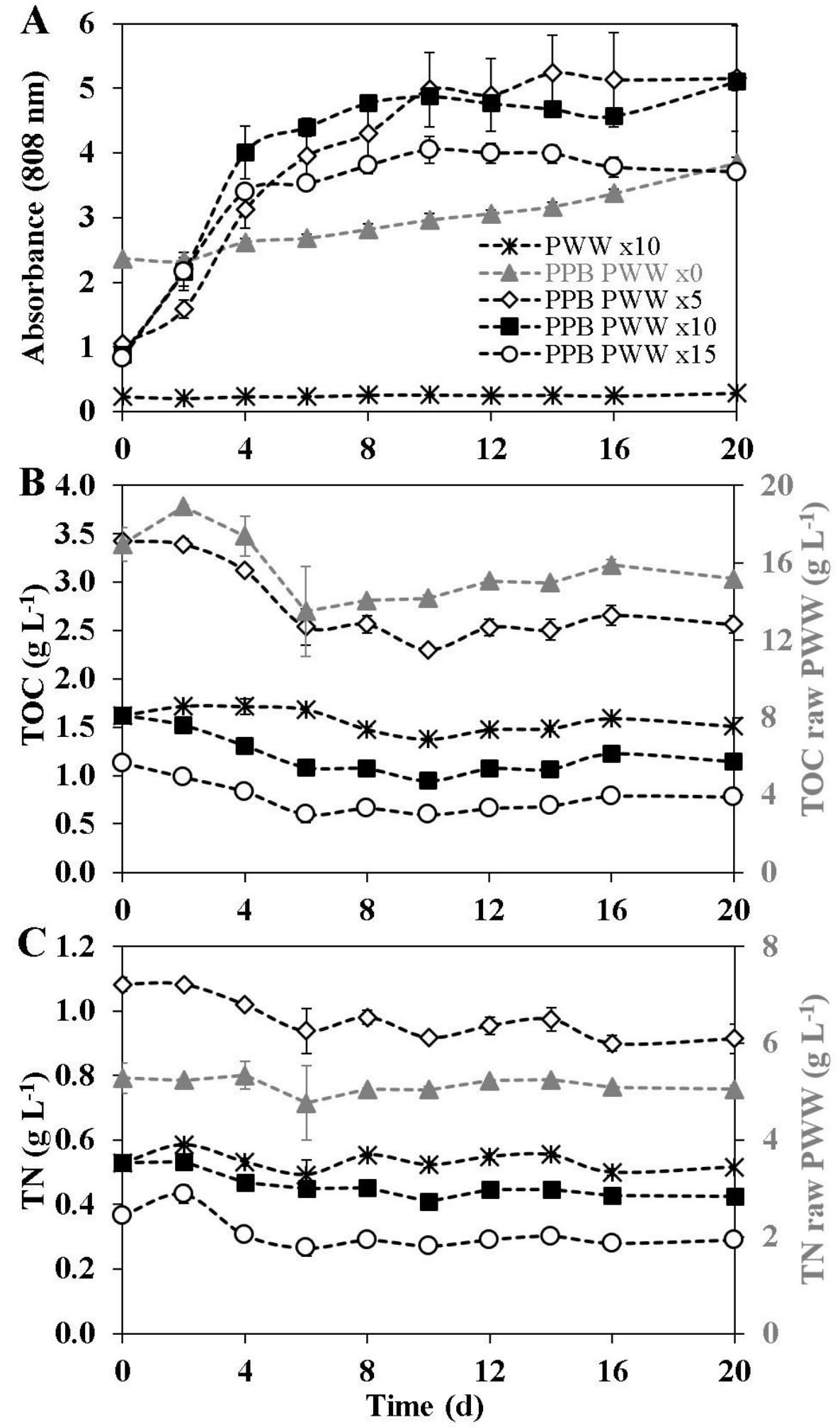
Figure 2.

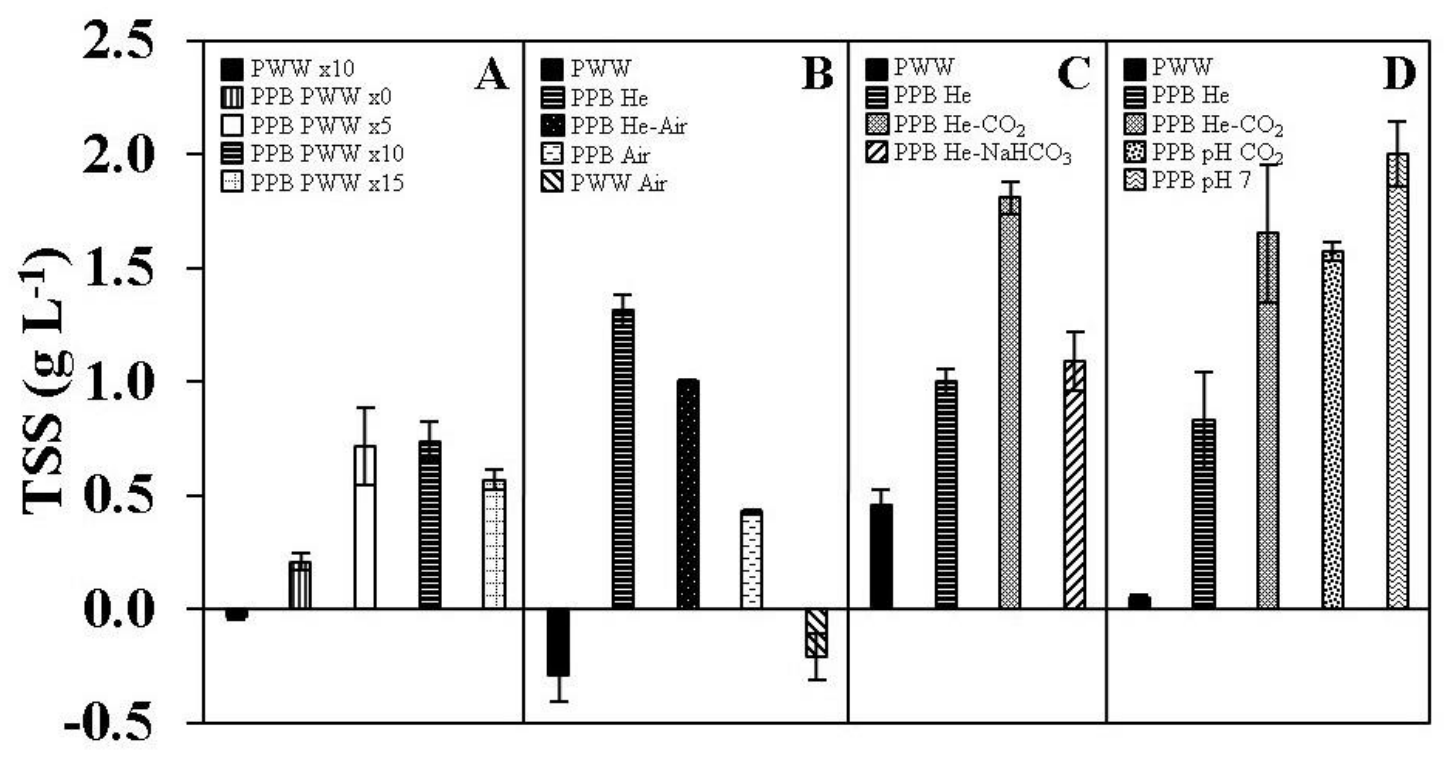

753

754

755

756

757

758

759

760

761

762

763 
Figure 3.
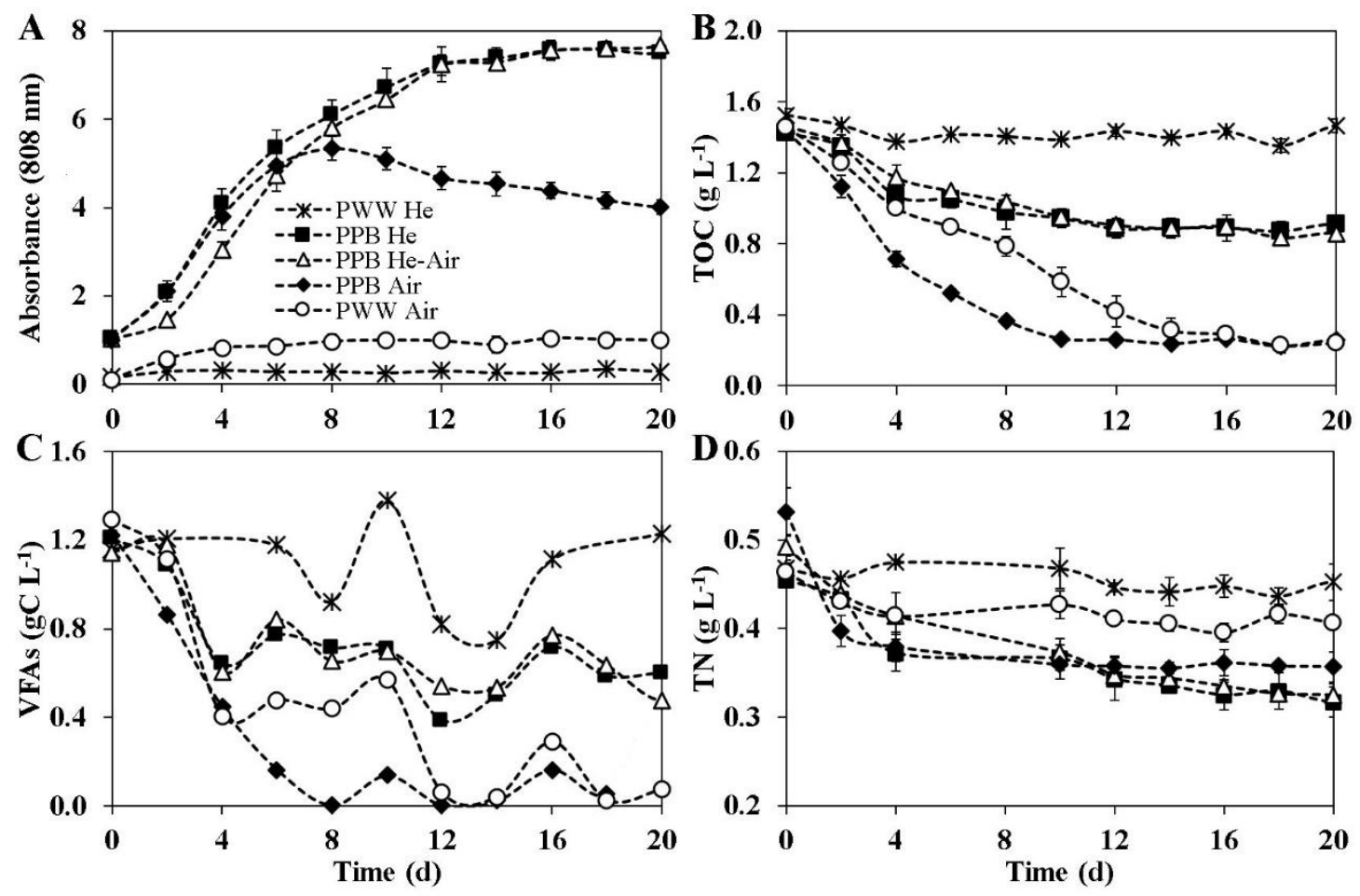
Figure 4.
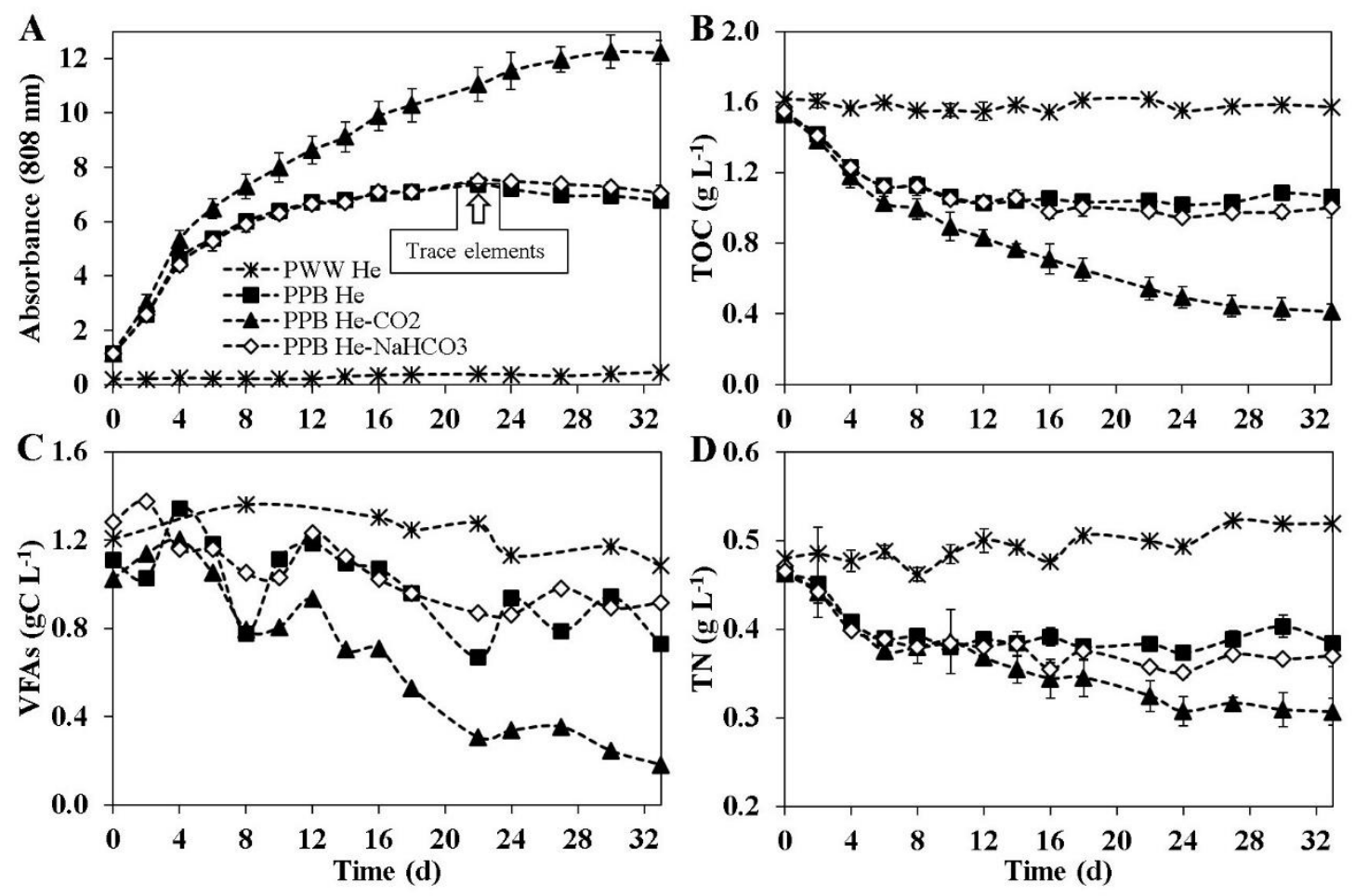

779

780

781

782

783

784

785

786

787

788

789

790

791

792 
Figure 5.
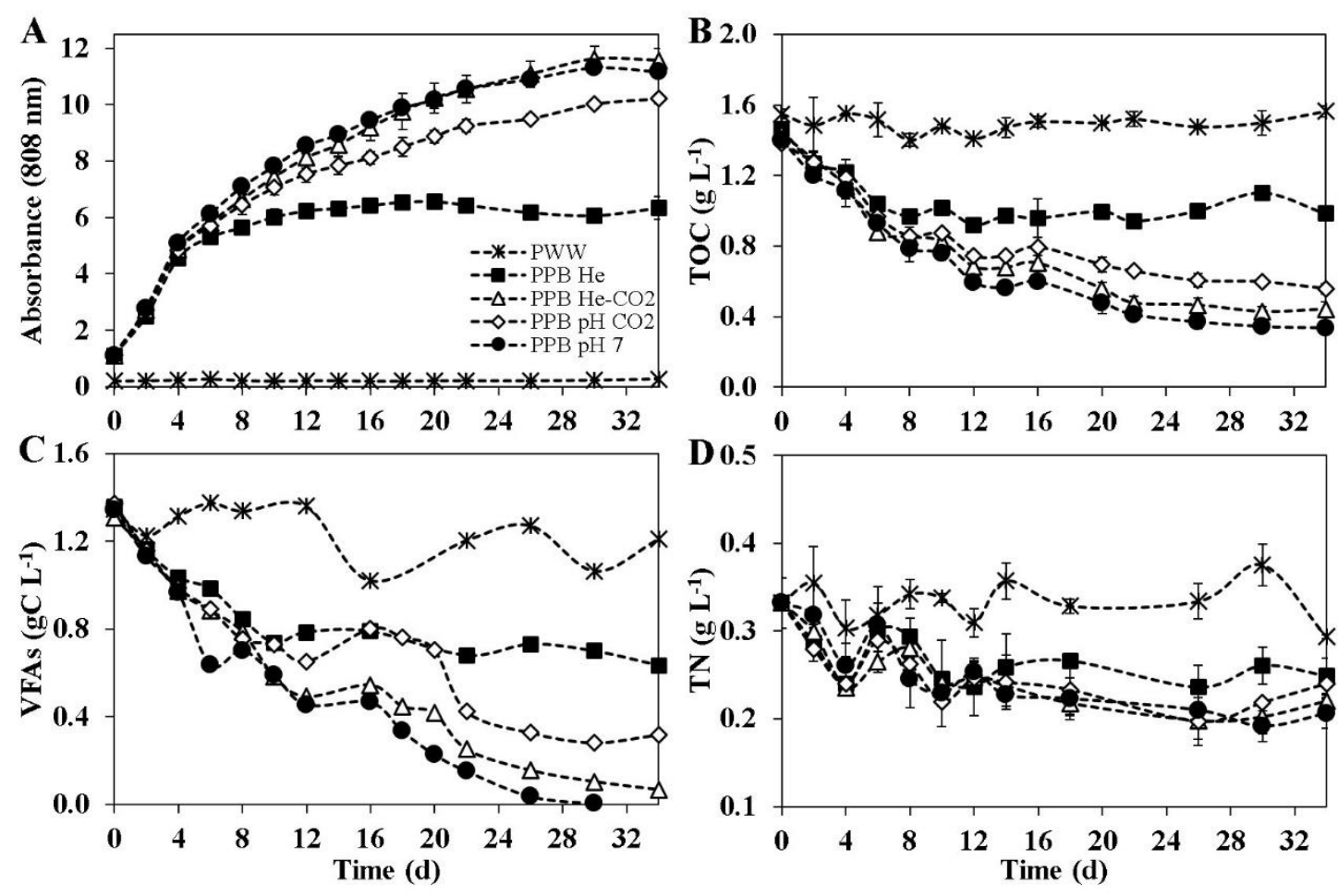

795

796

797

798

799

800

801

802

803

804

805

806

807

808

809 